\title{
Global Peaceful Change and Accommodation of Rising Powers:
} A Scholarly Perspective*

\author{
T.V. Paul \\ McGill University
}

\begin{abstract}
Can the accommodation of rising powers in the international system be accomplished peacefully? Prof. Paul, in his recent publication, argued that if the established and status quo powers hold grand strategies which allow for peaceful accommodation, this is feasible. He clarifies the differences between accommodation and appeasement and the value of soft balancing, relying on institutions, economic diplomacy, and limited ententes as mechanisms for restraining the aggressive behavior of major powers. Variations in current US policies toward Russia and China are discussed. Non-accommodation of major powers as well as minor powers has major internal and external consequences. He concludes by arguing that contemporary rising powers, such as China and India, have much greater prospects of rising peacefully than previous era great powers, partially due to the opportunities offered by the globalization process. However, these states must initiate economic and developmental programs for other states, without neocolonial overtones, in order to increase global development and their own status. The discipline of IR has a special duty to encourage students and policy makers to develop strategies of peaceful transformation, rather than war, as the main mechanism of change.
\end{abstract}

Keywords: Rising powers, peaceful change, US, China, India, Russia

One way of defining peace is to treat it as 'stability,' i.e. a condition in which major states are not fighting each other. Based on that, we can argue that if a rising power is given certain benefits and is fairly happy with them, then you have a peaceful adjustment or accommodation. The quintessential example that comes to mind when thinking about peaceful change is the replacement of the UK as the hegemonic power by the US in the Americas in the 1890s-early 1900s without any war between the two. But even that example was actually less peaceful than it appears. For example, in their chapter in Accomodating of Rising Powers, Ali Zeren and John Hall argue that the US actually pushed its way into the British order. ${ }^{1}$ One may call pushing one's way into something "peaceful" but it is obviously very different from the US being genuinely accepted by Britain as the rising power. Therefore, there is some difference of opinion about even the quintessential example of global peaceful change. Other cases of accommodation are either a product of war or a post-war settlement. For example, after Japan and Germany were defeated in World War II, they were accommodated as secondary allies,

T.V. Paul, James McGill Professor of International Relations, Department of Political Science, McGill University, Montreal, Canada. Email: t.paul@mcgill.ca.

*Editor's Note: This commentary is based on an interview which Seçkin Köstem and Gonca Biltekin conducted in March, 2017 with Prof. T.V. Paul of McGill University. He is the past president of International Studies Association (ISA)

1 A. Zeren and J. Hall, "Seizing the Day or Passing the Baton? Power, illusion, and the British Empire," in Accommodating Rising Powers: Past, Present, and Future, ed. T. V. Paul (Cambridge: Cambridge University Press, 2016), 111-30 
but not as great powers. The US has provided them with considerable benefits, including economic market access and concessional aid. Their relations since then have been peaceful, but they came as a consequence of defeat in the war.

In Accommodating Rising Powers, Paul talks about different strategies of accommodation. Ideological /normative accommodation takes place when both established and rising powers agree on the core ideological and normative frameworks of the international order. ${ }^{2}$ Territorial accommodation is when both major and rising powers agree on the territorial status quo, including the spheres of influence. There are also economic accommodation and institutional accommodation, where rising powers are given a place and voice in the economic and institutional frameworks of the emerging international order. ${ }^{3}$ The question is whether these can all be accomplished at the same time. For example, 'spheres of influence' is a much- contested term and recently has caused some concern. Russia is expanding into the Arctic, whereas China is pushing into the South China Sea. Both are claiming that these are legitimate areas of their spheres of influence, but they are also infringing upon the rights of smaller states.

\section{Accommodation versus Replacement and Appeasement}

One big mistake people make when discussing peaceful accommodation is to confuse the term with replacement. Peaceful accommodation does not necessarily include replacement of the great power with another one. The US's peaceful accommodation of, and replacement by, China in the emerging system are very different events. Moreover, unlike replacement, accommodation is a continuous process. Today, China is quite generously accommodated in economic terms, but there is no certainty as to what will happen if China's demands exceed the limits acceptable to the US.

Another mistake would be to confuse accommodation with appeasement. Appeasement usually takes place when the country making demands does not stop where it is supposed to. For example, when Hitler invaded Czechoslovakia, Britain would have been willing to accept that situation if Germany had stopped there. Appeasement is also sometimes beyond one's control. Countries appease others all the time. Right now, it is almost impossible to directly confront US policy in many parts of the world. Sometimes, appeasement is the only option because there are limitations on what even the great powers can do. Unless a country has extraordinary military power or diplomatic skill, countries choose to appease rather than adopt other options such as war. Appeasement can also be used as a way to delay, frustrate, or gain support domestically. For example, Chamberlain was not getting the domestic support he needed to fight a war against Germany. He had a very difficult time convincing the British population of the necessity to fight a war. The British were hoping that Hitler would be just like any other great power and that giving some concessions would make him happy and content. European history has many cases in which great powers would contest up to a point, and then they would be appeased and give up the more extraordinary demands. That was the historical pattern, so it was natural for the British to think that Hitler would follow suit. Hitler, of course, had a very large agenda which was not well-understood at the time. So, the question is, how far will the agenda of the revolutionary state or the challenger go, and at what point will they escalate? Let's take China and its land acquisition policies in the South 
China Sea as a case. Examining it from the point of view that one should not appease at all, then the only remaining option is war. ${ }^{4}$ That option would entail the US penetrating China's air defense zones and naval areas, and contesting the country's demands openly which would probably elicit a very negative response from the Chinese. They would eventually shoot back, which would mean substantial disorder. But there are other ways -normative and institutional methods- to challenge the status quo. In his forthcoming book, Paul deals with this form of restraint, i.e. soft-balancing. ${ }^{5}$

Soft-balancing is probably a better route than direct confrontation. But like other strategic approaches, it does not always guarantee success. It has failed in the past. Italy was softbalanced during its war with Ethiopia in 1935 through the use of League of Nations-mandated sanctions. Japan was also soft-balanced prior to the Second World War. Unfortunately, neither of these attempts stopped their pursuit of wider ambitions. Sometimes soft-balancing can be used by target states, for their own benefit. Russia, for instance, considers sanctions (a soft balancing tool) directed against it as being almost equal to a declaration of war. On the other hand, Russia has not changed its policies or taken other actions, hoping that over time, the status quo will become entrenched. They rely on the contested notion in international law that if a state holds onto a territory for a long period of time, then it becomes theirs. China seems to be relying on this notion as well; if it can hold onto its claims in the South China Sea for another 50-100 years, it will become overwhelmingly powerful and the international community will acquiesce. In occupied places in the world, one may expect that the local population will resist the occupation, as they do in Palestine. But who is going to fight to resist the occupation of artificially-made islets in the South China Sea? There are no human beings in the vicinity, so a local uprising is out of question.

\section{Accommodating Russia and China}

The current US record in accommodating Russia and China seems to depend both on their demands and their domestic politics. If China demands complete control over the South China Sea, such demands are unlikely to be accommodated by the US. On the other hand, it would be a total blunder if President Trump plays the protectionism card against China and tries to make China's economy suffer. The rising populism in the US may lead to some level of protectionism, but if a sudden change of policy seriously hurts the Chinese economy, the outcome will be increasing nationalism in China. Therefore, such a push for protectionism needs to be restrained and dramatic gestures which would make the Chinese very uncomfortable should be avoided. China has been accommodated quite a bit since 1972 when it obtained a seat at the United Nations Security Council. It has also been gradually accommodated in the World Trade Organization and other forums. Because China does not have a big stakeholder position in the World Bank and IMF, it is cleverly creating parallel institutions. This strategy has some value for the peaceful transitioning that the world hopes for, as long as they don't become instruments for security competition or dominance.

What should we expect with respect to the great powers' accommodation of Chinese claims on the South China Sea? I believe that the major powers will accommodate China when it comes to the territories that are beyond the 200-mile limit for smaller states or they

\footnotetext{
4 President Trump seemed to favor this option, at least initially, but he appears to have backed down recently in order to gain Chinese support for the North Korean nuclear issue.

5 T.V. Paul, Restraining Great Powers: Soft Balancing from Empires to the Global Era (New Haven, CT: Yale University Press, forthcoming).
} 
may agree to joint operations in some contested areas. Joint exploration, especially if it is done under international authority, seems to be a reasonable solution. The Chinese already have some joint operations with other countries in some parts of the larger Pacific. Similar arrangements could be made regarding the Arctic. Deciding who will get most of the benefits will still be a challenge, but it is likely that whoever has more capability will have more rights. That is the situation in Antarctica. A few countries, the ones with the ability to go there and establish their naval facilities early on, have already divided it up.

The current US record in accommodating Russia does not seem to be very good. Russia was a somewhat pacified state when Putin came to power. It was a period when NATO and the US could have attempted a better policy to accommodate Russia. By asking the Ukrainians and the Georgians to join NATO and the EU, the Western powers completely disregarded Russian sensitivity when it comes to its surrounding regions. This can be seen as a policy blunder, since they knew that Russia was very paranoid about its security. The country's anxiety is understandable since Russian history is filled with examples of Westerners, such as Napoleon and Hitler, coming in and attacking them through the surrounding countries. The European states, including the EU, also made a mistake by encouraging Ukrainians to trade with them exclusively. Trying to isolate Russia demonstrated a lack of political sensitivity on the part of the West and, unfortunately, calling on Obama for help was an even bigger mistake. Although its material power is in decline, Russia is still a great power and it wants to remain a great power. It was assumed that since the Soviet Union lost the Cold War, former Soviet Republics would join in the great democratic alliance. This demonstrates a serious failure to design a successful grand strategy of accommodation. We can partially blame liberal institutionalism, i.e. thinking that everyone will join because liberalism is always "correct" or that the future prospects of liberalism are better. However, by doing so, Western countries missed a great opportunity to accommodate Russia. Russia's subsequent military responses are part of the challenge created by the country's ongoing quest for higher status in the international system.

\section{Accommodation and Small Powers}

The great powers' accommodation of rising powers has serious implications for smaller powers. For instance, if the US decides to accommodate China, giving it control over the waters and resources within the Nine-Dash Line in the South China Sea, the consequences will be grave for the Philippines, Vietnam, Malaysia, and Brunei. All of these smaller countries claim parts of the same area and China is infringing upon the 200-mile zone that the law of the sea gives to them. It is increasingly hard to accommodate all of these countries and one cannot easily ignore them as the major powers did in the past. For example, during the second Italo-Ethiopian War of 1935, the British and the French were ready to give one third of Ethiopia to Italian dictator Mussolini in return for joining an alliance with them against Hitler. Mussolini's fascism was not a concern for the British at the outset. But once the secret agreement was leaked by a French newspaper, British Foreign Secretary, Samuel Hoare, had to resign because of the public outcry over the concessions they were willing to make. In the past, the great powers had a tendency to make decisions for the weaker states without their approval, even though the outcomes were not always successful. However, war in the decolonized world is a very different phenomenon. If major powers try to run over weaker states, there will be lot more opposition and resistance from the smaller states. 
The smaller states also have some responsibilities when it comes to accommodation of rising powers. They should be careful when confronting great powers, and should be cautious when considering their sovereign equality. Ukraine and Georgia should definitely have been careful with Russia. Similarly, some of the Baltic states' policies regarding their Russian minorities are pushing that group into some kind of second-class status. These policies may evoke Russian hostility. A similar situation exists in South Asia. The smaller states sometimes push India too much. Considering the material power differantial, the smaller states should refrain from taking unilateral actions and throwing themselves at the front line. Alternatively, they could use diplomacy and institutions to change the policies of the bigger state. Therefore, it is very important for small states to become active members of international and regional institutions, even if they are dominated by the rising powers. Bargaining through the institutional process is much more efficient than waging war or sustaining hostility.

\section{Consequences of Non-Accommodation}

Non-accommodation of a rising power has multiple consequences. The first one is internal unhappiness or resentment in such a state. For instance, there was a period when sanctions were placed on India because of its nuclear policies which generated hostility towards America, or the West in general. The general domestic perception in India was that it deserved more because it was a big democratic state and it have endured huge difficulties because of colonial powers. Similarly, the Chinese had the notion of "the century of humiliation." Non-accommodation does not necessarily lead to war, but it creates the conditions for ultranationalism and resentment. Moreover, lack of economic accommodation, for instance, would create a lot of poverty in these countries. Accommodation of China by Nixon and Kissinger in the 1970s laid the groundwork for China's opening to the world and helped the country's development. Without that accommodation, China would still be a very poor country and we might have had more cultural revolutions. More importantly, the idea of "peaceful rise" that Deng Xiaoping and successors brought forward would not have been possible if China had not been accommodated and still remained an isolated state. Therefore, viewing the consequences of China's accommodation through an economic lens is a very narrow way of looking at it. Despite the fact that almost every country now has a trade deficit with China, far more important values have been generated.

A second consequence of non-accommodation would be to shut off large segments of populations to the spread of global values. If China had been completely shut off, like North Korea today, there would be no lines of communication through which to get the message across. Therefore, accommodation is also providing opportunities for greater interaction and longer-term peace. Finally, non-accommodation may lead to spoilership by rising powers on a global scale. The disenfranchised or less accommodated great powers can provide support to regional states or they can offer assistance to domestic insurgencies and secessionist or irredentist groups, which disrupt regional order. China previously supported many Maoist insurgencies in different corners of the world such as South East Asia and South Asia. China and Russia currently spoil others' plans in the Middle East. A non-accommodated China can do a lot of harm and could also be a spoiler in global politics in other issue areas, such as climate change. Therefore, accommodation can help achieve not only strategic goals but also those related to maintaining order. 
The first question to ask when thinking about accommodation is "what will satisfy a challenger state?" The meaning of satisfaction changes from one actor to another, especially when it comes to notions like status. Some regional/smaller countries, like North Korea or Iran, have been regarded as having no limits to their ambitions, but this may not be the case. In my opinion, their primary goals are regime survival, which requires an accommodation strategy that is different from what is required for a great power. Mr. Putin also wants to survive, but Russia has often been driven by great power goals, too. The drastic policies enacted by these lesser powers, such as North Korea's nuclear acquisition, have primarily been undertaken to support regime survival. The non-proliferation literature has completely ignored this dimension, and has focused primarily on deterrence, treating North Korea as a power which has to be constrained at all costs. Looking at it from an accommodation perspective, we can see that the North Korean regime thought they could secure their survival only by obtaining nuclear weapons. Since we do not hear about war with North Korea as a feasible option, their thinking must have been accurate. However, it has now created a difficult situation because there are increasing costs, new boundaries have been drawn, and it will take a much greater effort to accommodate North Korea. It has also signaled to other regional states that they can get away with nuclear proliferation if they push hard enough. North Korea will potentially acquire an intercontinental ballistic missile (ICBM), which at some point will be able to reach California. Pacifying North Korea's behavior now would require getting the genuine support of other great powers, like China. Nuclear weapons can be a great equalizer in the hands of a small state which feels cornered.

In contrast to using discourse on North Korea, we see Mr. Trump taking a more belligerent stance against Iran. If he pushes too hard, Iran will likely end up having nuclear weapons. The regime will feel the need to take active measures for its own survival. Missile tests are intended to demonstrate their resolve to fight back. If they fail to do that, they will be looked down upon by their domestic population, which will damage the regime's survival. Creating a new rivalry situation with Iran is counterproductive. The nuclear proposal should be given a chance even if it does not guarantee that Iran will not try to gain nuclear weapons in 15 years.

Therefore, short of war, any strategy to topple well-entrenched regimes in regional contexts will not work. Their accommodation can actually be called status accommodation, i.e. accepting them as normal states and giving them certain opportunities to prove themselves as such. The India-US nuclear deal was a case of successful status accommodation. In a chapter in Status in World Politics, Paul and Shankar consider this agreement as having great symbolic value, because it not only removed India from the sanctions regime, but it also gave India the status it sought. ${ }^{6}$ Such targeted accommodation, tailored to the needs of the state in question, can be very useful. The hope is that these agreements will slowly accommodate the state over a period of time, so that it has time to adjust its behavior. The Obama administration's expectation with the Cuban deal, for example, was that once the Cubans realized the benefit of trade and human interaction, it would change the way they behave. Of course, such policy requires examination of Cuban and North Korean perceptions and needs. 


\section{Opportunities for Change}

The definition of great power status is changing. Look at the Concert of Europe, for example. Once upon a time, five great powers could sit in Vienna and determine the fate of the world. They could decide the frontiers and divide the countries. Someone sitting in London could decide on the border between India and Pakistan, India and China, or Kuwait and Iraq. They did not need the approval of any other parties, including the populations living in the respective territories. That era no longer exists. The great powers of today do not have such complete control over the destinies of non-great power states. They face institutional, economic, and ideational challenges and it is not easy for any state to force its way into hegemony. Although great powers still have a big voice in the way regional and international orders are maintained, the world has multiple centers of power. There is potential for US decline looming on the horizon. Mr. Trump is trying to arrest that possibility, using techniques with which the US power elites are comfortable. The problem is, however, that those techniques may not work in the much more globalized world of today. Even if they do, they create a lot of dissonance and potential violence. Therefore, whichever country wants to become a great power, will have to craft a better strategy of peaceful rise.

The rising powers have a great opportunity today for peacefully achieving their goals. Despite the challenges, they could start new programs that benefit the rest of the world. We must not forget that events like the 2008 financial crisis were breeding grounds for innovation for the rising powers. Brazil is in deep economic trouble right now, but India and China, for instance, could lead the way in creating more opportunities for the less privileged and help build a new world order, without neo-colonial overtones. They can do it at least in the ideational/normative realm by providing alternative perspectives to challenge Trump's outdated idea of imposing American hegemony or Putin's militarist solutions.

On the other hand, such attempts should not have to stop at the normative level. At the institutional level, China is already expanding its influence through infrastructure support in developing countries, including its friends in Africa, South Asia, Latin America, and Central Asia. The One Belt, One Road (OBOR) program offers much hope but also some dangers. If China securitizes the project and uses its economic clout to dominate or exploit its clients, conflict could occur. Pakistan has recently become a recipient of huge Chinese investment. The China-Pakistan Economic Corridor (CPEC) is a big transportation and communication connectivity project. China built a port city in Gwadar, Pakistan, on the Arabian Sea, which has great potential if China builds industries there and establishes economic free zones. But, it may pose challenges as well. China appears to deploy its navy in the Gwadar Port. Once the Chinese navy comes in, the Indians and the Americans will not be able to remain aloof; and they will send their navies to the Arabian Sea to compete. This has been the pattern in the past. Colonialism began with entities like the British East India Company starting as a trading company and setting up little trading posts in Kolkata, Madras, and Bombay. After a while it "needed" an army to go into the interiors of the country and it then managed to penetrate the entire subcontinent. There is somewhat the same risk of colonialism from China, despite their subtlety compared to earlier British and contemporary Russian approaches. One cannot be sure about how far they will succeed. Since Pakistani workers with higher technical skills are few, Pakistan does not benefit very much from the employment opportunities. Chinese workers, who are willing to work long hours for meagre compensation, are coming in to 
work. Much local resentment is building up. Combined with the insurgent tendencies in Balochistan, there is a fear of sabotage. Moreover, China provides loans, not grants. If these projects fail to generate the income they are supposed to provide, China may have to write off the debt or Pakistan will have to borrow money to pay off the debts. Despite these risks, Chinese development and infrastructure strategy appears to be better than its alternatives, especially those provided by Western countries.

India is following a somewhat similar course. It wants to spread its economic activities to the Association of Southeast Asian Nations (ASEAN) countries by building a NorthEast Corridor and is involved in developing the Iranian port of Chabahar and a highway to Central Asia. Nevertheless, China and India need not compete all the time. They have successfully cooperated in oil exploration in Central Asia. Rather than splitting the continent into two distinct spheres of influence, both countries can cooperate by creating economic, institutional, and other mechanisms.

However, whether such schemes can turn the game into a mutually useful, non zerosum one, depends very much on the statesmanship of the ruling elite. In the past, many opportunities were missed because of a lack of such statesmanship and global leadership. Today, there are few global leaders whom the world can look up to. Obama was the closest, but it is questionable whether he succeeded in creating that kind of synergy in every part of the world. Some of his policies were very contradictory, especially in the Middle East. I believe it was a total failure in Libya and Syria. The so-called liberal interventions did a lot of harm, and several countries, including Turkey, are suffering because of them. Angela Merkel is probably the most influential European leader with a level-headed vision, but she is challenged by many others. The recent French election creates some hope that a young dynamic leader with a progressive vision will emerge in Europe. However, statesmanship is not confined to the top leaders alone. Middle level diplomats are also very important players. The European Union, for example, was born out of, and has been sustained through, the efforts of such mid-level diplomats and bureaucrats. Part of the challenge is to find the right people, ones who have broad perspectives for solving the problems of the world. Unfortunately, both the current liberal and the increasingly conservative/populist elite in the West have rather limited understandings based on their ideologies. As someone who has engaged some of them, I must say that liberals are as much prone to nativism as are conservatives, and that is alarming.

The Chinese did a better job in devising a workable strategy by way of the so-called Peaceful Rise. Unfortunately, under Xi Jinping, China's foreign policy has moved into an assertive phase, which is probably going to hurt both China and others. On the other hand, Jinping is emerging as the biggest supporter of globalization. At the Davos meeting in 2017, he described globalization as a double-edged sword; and reiterated the Chinese proverb, "Honey melons hang on bitter vines; sweet dates grow on thistles and thorns." It was a very interesting analogy, highlighting the opportunities globalization presents. His support is all the more important when we think about the opposite trend, i.e. the rise of populist and isolationist leaders in the democratic West.

A world dominated by China will resemble the tributary system, which has some followers. The tributary system is an international order where smaller countries receive trade benefits,

"Full Text of Xi Jinping Keynote at the World Economic Forum," CGTN America, January 17, 2017, https://america.cgtn. com/2017/01/17/full-text-of-xi-jinping-keynote-at-the-world-economic-forum 
market access, and protection in return for paying tributes and not questioning the empire's hegemony. In some ways, it resembles the United States' arrangement in the Americas. Its working is made clear by the fact that while Canada can make occasional objections to a given trade policy, it will not seriously question the US primacy. This is true for Mexico to a greater extent. The Monroe Doctrine itself is very much like a tributary system, a fact not quite understood by Mr. Trump.

\section{Peaceful Change and the Southern Perspectives}

Unfortunately, IR has been particularly lacking in understanding and explaining some of these processes. When we look at the mainstream journals and books in the field, we see that, as a distinct topic, peaceful change at the global level receives little attention. There are very few publications on the issue and apart from the Chinese discussion on Peaceful Rise, most of them are written from a Western liberal view. The accounts about European historical experience, Cold War experience, or post-Cold War era, keep growing but there is little input from elsewhere. There are only a few IR scholars who look at history beyond the 500-years of European hegemony. ${ }^{8}$ The study of civilizations also has great potential in enriching IR. It can help us understand why we have such conflict in the Middle East. I think we should move beyond Huntington's idea of civilizational conflict, since there are also intra-Islamic tensions. When does the Sunni-Shia divide get accelerated? How is it related to different pathways of nation building, nationalism, international, and regional order? The political elite in some countries, like China, seems to have contributed to novel forms of International Relations thinking more than the IR scholars themselves. An interesting research question would be why globalization is so appreciated by rising powers like China and India, even when the so-called established states want to move in the other direction.

In the ISA 2016 Presidential Address, I looked at the issue of peaceful change and explored non-Western contributions. ${ }^{9}$ Gorbachev's contribution in ending the Cold War, the Chinese policy of peaceful rise, India's non-alignment, and the Bandung spirit were important cases in point. Brazil, South Africa, and Indonesia have developed their own versions of a similar non-hegemonic attitude of peaceful co-existence. Whereas there have been such contributions in the policy realm, the intellectual and scholarly works on those ideas remain inadequate. Non-alignment, for instance, could have inspired a theoretical account as to how those small states managed to challenge the two super powers. In a book chapter I am currently writing, I call it a very rare example of soft balancing by weaker states. Another example of innovative theorizing was dependency theory from Latin America, but I think the world has moved beyond dependency. Therefore, the International Relations discipline was not particularly successful in coming up with alternatives to mainstream theories. The existing alternatives such as post-modern or post-colonial theory also have limitations. They need to have greater interactions with different perspectives, especially those from the Global South. At ISA, we have a Global South Caucus. In 2016, I initiated a presidential task force on the Global South in collaboration with the Caucus. The primary motive was to start talking about the issues that we face in the Global South in particular. Take, for instance, the current crisis on the US travel ban on citizens of some Muslim countries. A lot of Western liberals in the ISA have also supported the campaigns against the ban, but the problem is that we usually treat

\footnotetext{
8 For a refreshing IR take on East Asian history, see David C. Kang, East Asia Before the West: Five Centuries of Trade and Tribute (New York: Columbia University Press, 2010).

9 T.V. Paul, "Recasting Statecraft International Relations and Strategies of Peaceful Change" (Presidential address at the International Studies Association (ISA), 57th Annual Convention, Atlanta, March 17, 2016), accessed April 13, 2017, http://www. $\mathrm{mcgill} . \mathrm{ca} /$ politicalscience/files/politicalscience/isa_presidential_address.pdf.
} 
these policies in isolation. Such policies have been implemented since 9/11. For example, a popular Indian Muslim actor Shahrukh Khan, whose 2010 film "My Name Is Khan" dealt with racial profiling in the United States, has been detained in US airports several times over the past years. A former President of India, Abdul Kalam Azad, was a Muslim and he was body searched once at a US airport.

Those who are fighting the travel ban should take into account the broader context and the process of which the ban is a part. If we want change, we need to move beyond talking about national policies only, and focus on the micro-level. We need to think about educating security and customs officials working at Borders to become more sensitive to racial diversity. Such training should incorporate comprehensive understanding of the cultural differences, tolerance, and an appreciation of different people. At ISA, we have the opportunity to be more global and bring in more ideas, perspectives, and resources. Many people from the Global South cannot attend conferences, because of lack of resources. We need to address that reality by raising resources in different countries like Turkey and India, and then strive to redistribute them in an equitable manner. This is one micro-level effort which directly contributes to the exchange of ideas, development of joint resource projects to study longterm historical processes and comparative regional experiences.

We need to look into strategies to confront the most hard-pressing problems of the world in our research. The IR scholars in the North should be sensitive and have an appreciation of the historical experiences in other places. South Asia is a great theatre for all the processes from balance of power to civilizational peace. Some of the Mughal emperors managed to develop very eclectic ideas on governance and social order. For instance, Akbar the Great, highlighted the need and suggested ways to be tolerant. The great Indian mystic poet, Kabir Das, was brought up as a Muslim yet he influenced Hinduism's Bhakti movement and Sikhism's scripture (Adi Granth). One can also encounter eclectic religions such as Sikhism, which is a combination of Islam and Hinduism. Sufism is also an interesting innovation, which moved beyond a binary worldview. The scholars from the Global South should study these ideas from other parts of the world using the same methods. We need to think through why such studies do not receive much attention. What are the major mechanisms that can incorporate these regional ideas into acknowledged scholarship? That's the challenge in for creating a more global IR.

\section{Bibliography}

Kang, David C. East Asia before the West: Five Centuries of Trade and Tribute. New York: Columbia University Press, 2010.

Paul, T.V. "Recasting Statecraft International Relations and Strategies of Peaceful Change." Presidential Address at the International Studies Association (ISA), 57th Annual Convention, Atlanta, March 17, 2016. Accessed April 13, 2017. http://www.mcgill.ca/politicalscience/files/politicalscience/isa_presidential_address.pdf.

— Restraining Great Powers: Soft Balancing from Empires to the Global Era. New Haven, CT: Yale University Press, forthcoming, 2018.

Paul, T. V., ed. Accommodating Rising Powers. Cambridge University Press, 2016.

Paul, T. V., Deborah Welch Larson, and William C. Wohlforth, eds. Status in World Politics. Cambridge University Press, 2014.

Zeren, A., and J. Hall. "Seizing the Day or Passing the Baton? Power, illusion, and the British Empire." In Accommodating Rising Powers: Past, Present, and Future, edited by T. V. Paul, 111-30. Cambridge: Cambridge University Press, 2016. 